\title{
Conservation assessment of the endemic plants of the Tuscan Archipelago, Italy
}

\author{
Bruno Foggi, Daniele Viciani, Riccardo M. Baldini \\ Angelino Carta and Tommaso Guidi
}

\begin{abstract}
The Mediterranean islands support a rich diversity of flora, with a high percentage of endemic species. We used the IUCN categories and criteria to assess the conservation status of 16 endemic plant taxa (species and subspecies) of the Tuscan Archipelago, based on data collected during field surveys over 4 years. Our data were sufficient to use criteria $\mathrm{B}, \mathrm{C}$ and $\mathrm{D}$ in our assessment. We used criterion $B$ in the assessment of all 16 taxa, criterion $C$ for four taxa, criterion D for 11 taxa and criteria B, C and $\mathrm{D}$ for three taxa, Centaurea gymnocarpa, Limonium doriae and Silene capraria. According to our results L. doriae, Romulea insularis and S. capraria are categorized as Critically Endangered and therefore require immediate conservation measures; eight taxa are categorized as Endangered, two as Vulnerable and three as Near Threatened. Compared to earlier assessments, eight species are recategorized with a higher degree of threat, two species are recategorized with a lower degree of threat, five are unchanged, and one species is assessed for the first time. Based on the IUCN categorization our results show that all the endemic species of the Tuscan Archipelago are directly and/or indirectly threatened by human activities, such as tourism and agriculture, and invasive species of plants and animals. The Tuscan Archipelago National Park is responsible for the conservation of all endemic species in the area.
\end{abstract}

Keywords Conservation, endemic, flora, islands, IUCN Red List, Mediterranean, threatened species

This paper contains supplementary material that can be found online at http://journals.cambridge.org

\section{Introduction}

$\mathrm{T}$ he Mediterranean region, with almost 5,000 islands and islets (de Montmollin \& Strahm, 2005), is known for its high plant diversity and is recognized as one of 34 Global Biodiversity Hotspots (Mittermeier et al., 2004).

BRUNo FogGi (Corresponding author), DANIELE Viciani, RicCARDo M. BALdiNI and Tommaso Guidi Department of Evolutionary Biology, Laboratory of Plant Biology, University of Florence, Via La Pira 4, I-50121 Florence, Italy E-mail bruno.foggi@unifi.it

Angelino Carta Department of Biology, Botanic Garden, University of Pisa, Italy

Received 14 July 2012. Revision requested 18 October 2012.

Accepted 20 February 2013. First published online 31 July 2014.
Circa 25,000 species are native to the region, with a high percentage of endemism (50-59\%: Greuter, 1991; Médail \& Quèzel, 1997), and the archipelagos of the Mediterranean are thus a natural laboratory for evolutionary studies (Thompson, 1999).

A taxon is considered endemic when its distribution is circumscribed to a well-defined geographical district (Anderson, 1994; Cuttelod et al., 2008). Endemic taxa may be defined as rare and potentially threatened (Ellstrand \& Elam, 1993; Fjeldså, 1994; Linder, 1995; Ceballos et al., 1998; Myers et al., 2000; Işik, 2011), and therefore they may be considered conservation priorities (Schnittler \& Ludwig, 1996; Gruttke et al., 1999). Populations of many species have declined (Butchart et al., 2010; SCBD, 2010) and extinction rates exceed background extinction rates by two to three orders of magnitude (Pimm et al., 1995).

The most authoritative source of information on the global conservation status of species is the IUCN Red List (Miller et al., 2007), which uses objective standards based on the assessment of extinction risk at the global level to provide researchers with a system for comparing data (IUCN, 2001, 2011; Mace et al., 2008).

The IUCN Centre for Mediterranean Cooperation and the IUCN Species Survival Commission have highlighted plant conservation and assessment as regional priorities for action (Delanoë et al., 1996). A project to assess the conservation status of 454 aquatic plant species and 19 subspecies in the Mediterranean was carried out during 2007-2010 (IUCN, 2013) and an evaluation of Mediterranean endemic plants is in progress. However, there has not been sufficient research examining the extent to which global criteria are applicable to small geographical regions such as islands (Martin, 2009). Although there has been some research on individual taxa (de Montmollin \& Strahm, 2005; Fenu et al., 2011, 2012), few projects have used the IUCN categories to assess the status of endemic flora for regional red lists (Domínguez Lozano et al., 1996; Médail \& Verlaque, 1997; Trigas et al., 2008) and few have focused on entire archipelagos (Costion et al., 2009; Martin, 2009).

The Conservation Working Group of the Italian Botanical Society has initiated an evaluation of the Italian flora to establish a National Red List (Rossi \& Gentili, 2008). Several taxa of the endemic flora of the Tuscan Archipelago are listed in Conti et al. (1997) and Sposimo \& Castelli (2005); however, to date, only one species in the archipelago (Centaurea gymnocarpa; Foggi, 2005) has been evaluated using the IUCN criteria. Consequently, we started an extended work to assess 


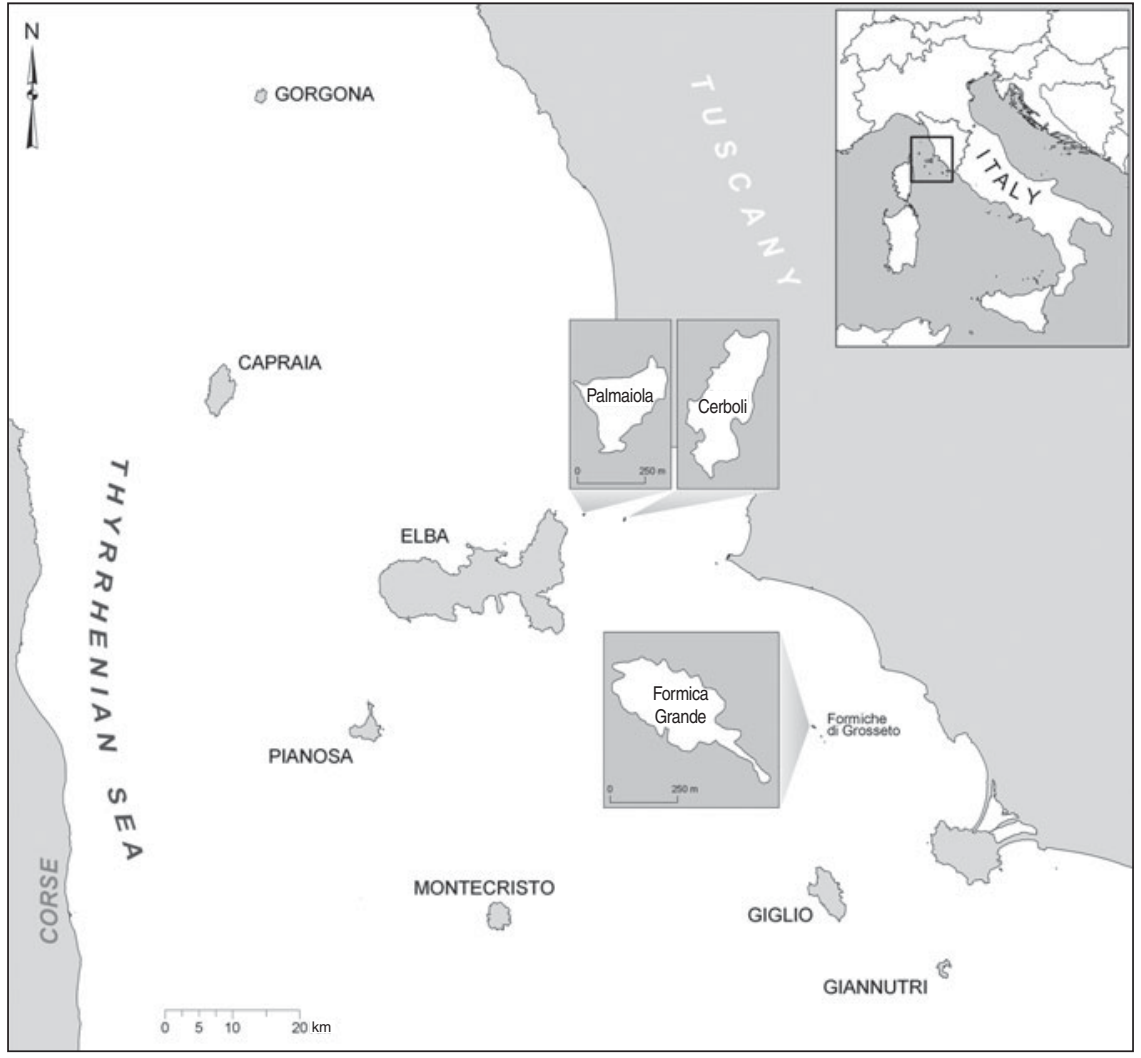

FIg. 1 The islands of the Tuscan Archipelago. The rectangle on the inset shows the location of the main map off the coast of Italy. all the rare and vulnerable plants of the Tuscan Archipelago. Our aim here is to assess all the endemic vascular plants of the Archipelago, based on IUCN criteria (2001, 2011), and highlight threats to the flora in this territory.

\section{Study area}

The Tuscan Archipelago comprises seven islands and c. 20 islets (Fig. 1). It originated with the rotation of the CyrnoSardinian tectonic plate and the consequent evolution of the northern Apennine. The flora of the archipelago consists of c. 1,400 taxa, $80 \%$ of which are herbaceous, reflecting the Mediterranean setting and the prevalence of secondary forms of vegetation; $1.14 \%$ of the taxa are strictly endemic, most of which are related to Cyrno-Sardinian elements, suggesting that the Tuscan Archipelago is a biogeographical bridge between the floristic Cyrno-Sardinian dominion and the Italian peninsula. The landscape of the region has changed significantly over recent decades as the traditional economy based on pastoralism, forestation and cultivation has given way to an economy based mostly on tourism (Papayannis \& Sorotou, 2008).

\section{Methods}

\section{Species}

The conservation status of the 16 plant taxa (species and subspecies) endemic to the Tuscan Archipelago (Table 1) was assessed using the IUCN criteria and guidelines (IUCN, 2001, 2011). The species included those listed by Arrigoni et al. (2003), with the addition of Crocus ilvensis (Peruzzi \& Carta, 2011). Contrary to a previous report (Fossi Innamorati, 1991), and in accordance with Frignani \& Iiriti (2011), Romulea insularis is considered an endemic species of Capraia Island.

Three of the five IUCN criteria were employed. Criteria $\mathrm{A}$ and $\mathrm{E}$ were not used because there is insufficient information to assess population dynamics or estimate the minimum viable population. Three main types of information were available for assessment: distribution, population sizes and threats.

\section{Distribution data}

The distribution data were obtained from field surveys, museum collections (only records from 2005 onwards were used) and a georeferenced phytosociological database of $>1,000$ relevés and permanent plots (from the Laboratory of Plant Biology, Department of Biology, University of Florence). For herbarium specimens and information from phytosociological relevés (mainly collected for vegetation mapping; Foggi et al., 2006, 2008, 2011a; Foggi \& Pancioli, 2008; Viciani et al., 2011) we discarded all records with a georeferencing uncertainty of $>500 \mathrm{~m}$. We conducted field surveys during 2007-2010, from early spring to late summer, to investigate the species localities reported in the historical floristic bibliography on the area, check for species presence 


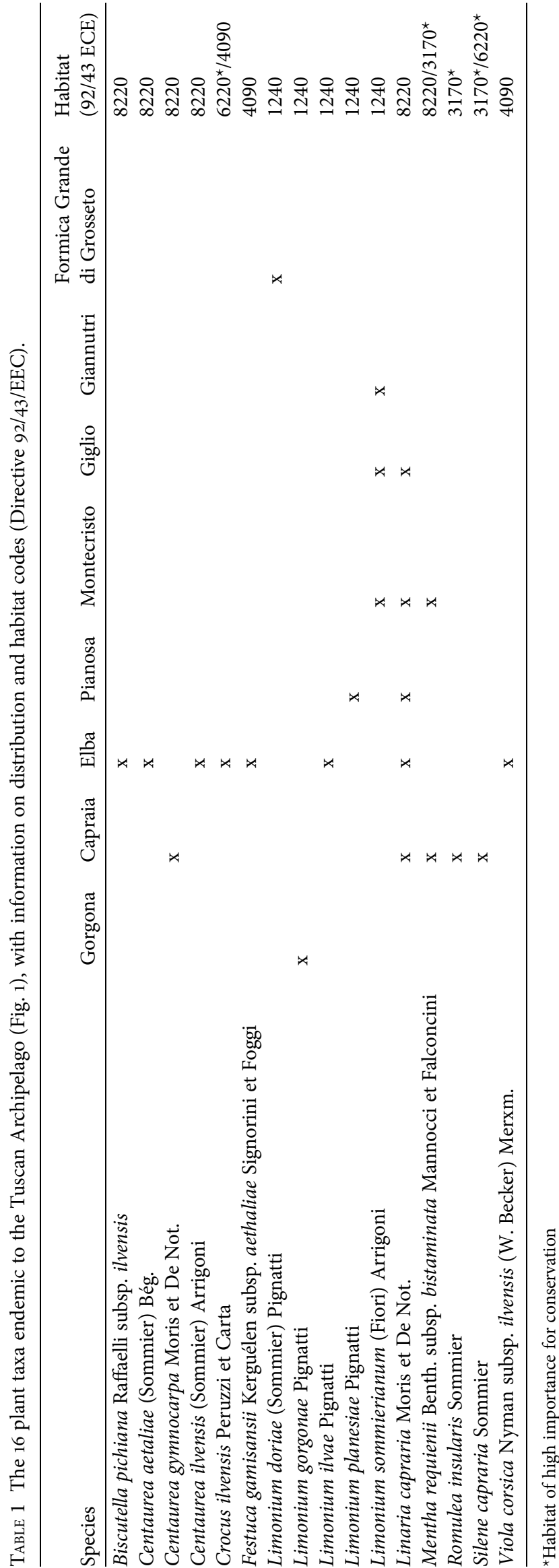

data, complete the distribution information, count mature individuals, detect typical habitats of the different taxa, and identify threats and pressures. We recorded the geographical coordinates of each individual, using a global positioning system, to an accuracy of $\pm 10 \mathrm{~m}$.

All geographical data were plotted using ArcGis v. 10 (ESRI, Redlands, USA). The distribution information was used to compute Extent of Occurrence and Area of Occupancy of each species, following the IUCN guidelines for applying criterion B (IUCN, 2011). Extent of Occurrence was obtained by delimiting a polygon that encompassed all the known localities of a taxon. For species that occurred on several islands (e.g. Linaria capraria) the polygon was computed with the exclusion of the sea areas between islands (IUCN, 2011). Area of Occupancy was calculated by overlaying a $4 \mathrm{~km}^{2}$ Universal Transverse Mercator (UTM) grid on the maps and summing the areas in which each species was located. Because of the narrow distributions of the species and the detail of spatial information available we also calculated the Area of Occupancy using a grid of $1 \mathrm{~km}^{2}$. A $1 \mathrm{~km}^{2}$ grid can be used for assessment when highprecision data are available (IUCN, 2011). The Extent of Occurrence was often lower than the Area of Occupancy for narrowly distributed species. In such cases the Extent of Occurrence was taken to be equal to the Area of Occupancy (IUCN, 2011).

\section{Population size}

Population sizes were estimated for the application of criteria $\mathrm{C}$ and $\mathrm{D}$ by sampling or by counting all mature individuals. All individuals were counted where the population was well circumscribed and comprised few individuals. Where this was infeasible the population was sampled. Sampling was carried out on Elba, Capraia and Formica di Grosseto Islands in a single survey, counting only mature individuals.

On Elba sampling mostly followed a random stratified design. Ninety-eight plots of $5 \times 5 \mathrm{~m}$ were selected randomly in the habitats preferred by the endemic taxa, as indicated by Guidi (2010). Habitats were identified in the field on the basis of the vegetation map of Foggi et al. (2006). The number of individuals was estimated using:

$$
N_{s}=\sum_{i=1}^{n}\left(\frac{u_{i}}{25} S_{i}\right)
$$

where $N_{s}$ is the number of individuals of a species, $\mu_{i}$ is the mean number of individuals in habitat $i$, and $S_{i}$ is the total area of habitat $i ; \mu_{i} / 25$ is the density per $\mathrm{m}^{2}$ (Guidi, 2010).

On Capraia, Formica di Grosseto and some parts of Elba sampling was carried out using a simple random design, with 46,40 and 76 plots, respectively, without stratification as the surveyed species were distributed within a single 


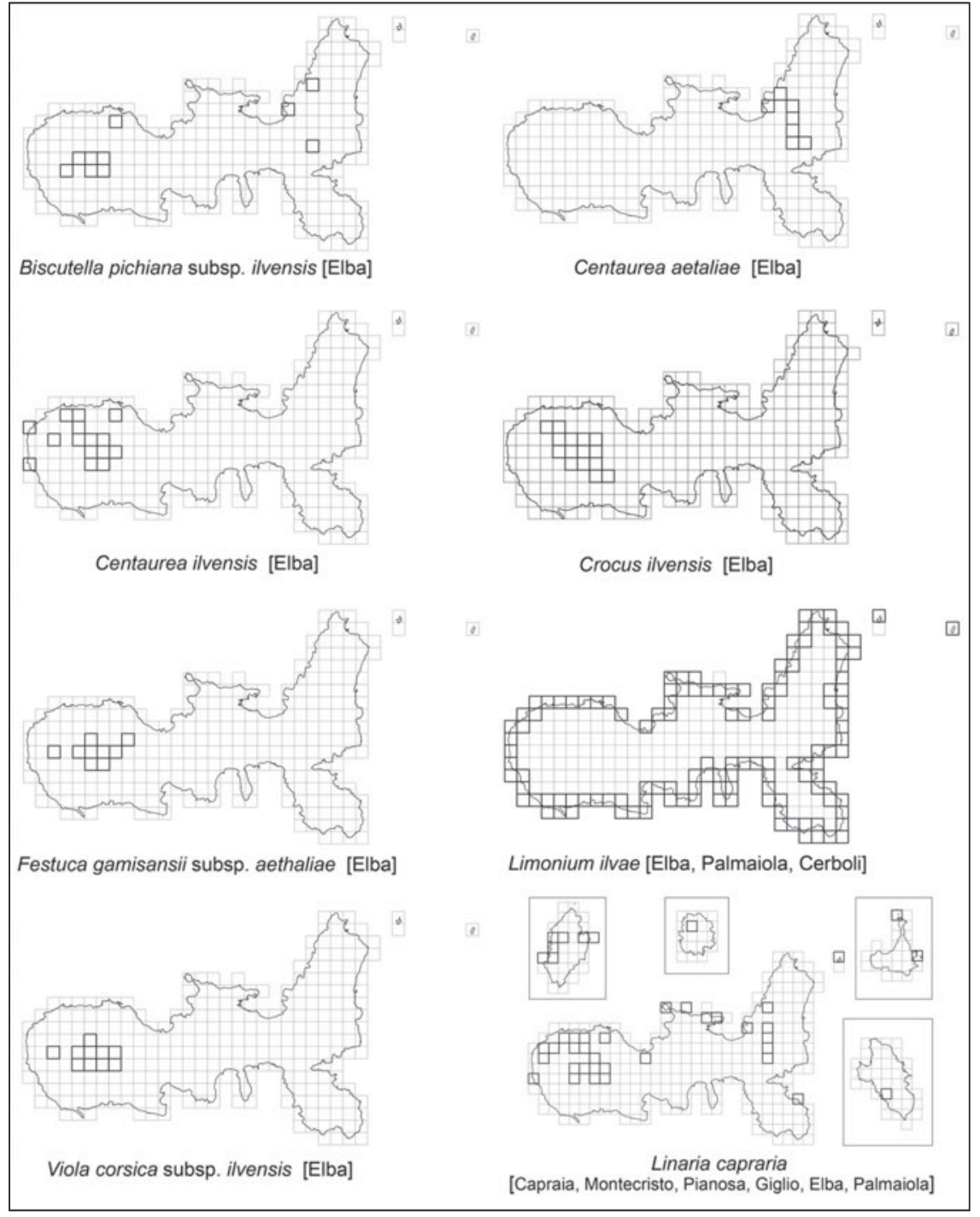

Fig. 2 The Area of Occupancy (grid $1 \times 1 \mathrm{~km}$ ) of eight endemic taxa in the Tuscan Archipelago (Fig. 1): Biscutella pichiana subsp. ilvensis, Centaurea aetaliae, Centaurea ilvensis, Crocus ilvensis, Festuca gamisansii subsp. aethaliae, Limonium ilvae, Viola corsica subsp. ilvensis and Linaria capraria. habitat (Guidi, 2010; Peruzzi \& Carta, 2011). Given the narrow distributions of the species surveyed, each plot was $1 \mathrm{~m}^{2}$. The number of individuals was estimated using:

$$
N_{s}=\mu_{i} S_{j i}
$$

where $N_{s}$ is the number of individuals, $\mu_{i}$ is the mean number of individuals per plot of the $i$ th species (in this case, the mean number of individuals per $\mathrm{m}^{2}$ because the plot size is $1 \times 1 \mathrm{~m}$ ) and $S_{j i}$ is the area of the $j$ th habitat for the $i$ th species (Guidi, 2010). The data collection methods employed for each species are summarized in Supplementary Table S1.

\section{Locations}

We defined the number of locations according to the distribution of populations and the threats affecting them, based on IUCN (2012).

Although the term locations may be considered subjective (Robbirt et al., 2006) we followed the IUCN
(2011) guidelines that define a location as 'a geographically or ecologically distinct area in which a single event can rapidly affect all individuals of the taxon'. We considered subpopulations of the same species from different islands as belonging to different locations because, given the distance between them, a threat affecting one subpopulation could not threaten the whole species with extinction. On a given island we considered that all individuals of the same taxon living in adjacent cells belonged to the same subpopulation, following Rivers et al. (2009).

Risk value

For each taxon we defined a synthetic risk-value index considering the increase in the risk of extinction, assigning numerical values to IUCN categories: Near Threatened $=1$, Vulnerable $=2$, Endangered $=3$ and Critically Endangered $=4$. The total risk value is the sum of the risk values of all the taxa of the Archipelago. 


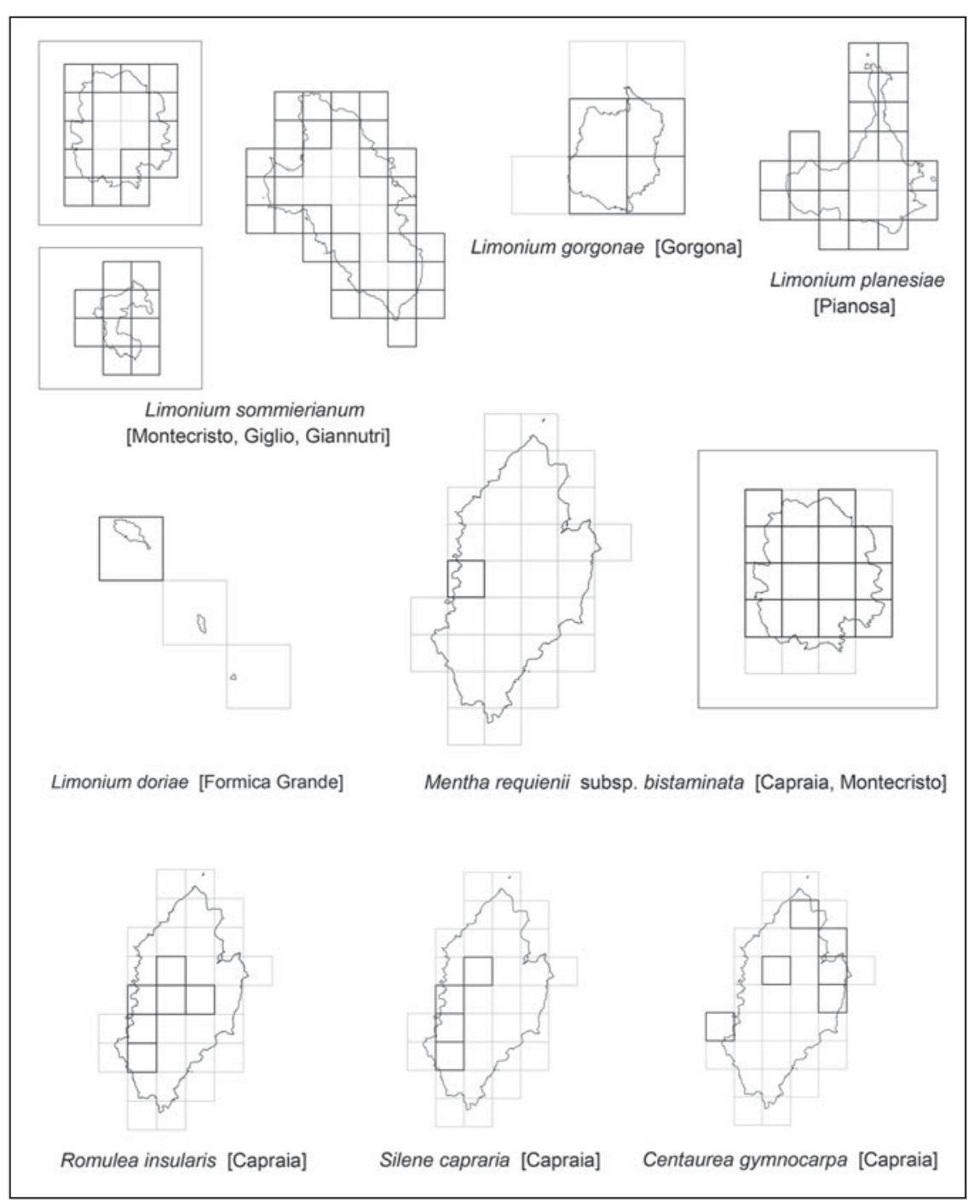

FIg. 3 The Area of Occupancy (grid $1 \times 1 \mathrm{~km}$ ) of eight endemic taxa in the Tuscan Archipelago (Fig. 1): Limonium sommierianum, Limonium gorgonae, Limonium planesiae, Limonium doriae, Mentha requienii subsp. bistaminata, Romulea insularis, Silene capraria and Centaurea gymnocarpa.

\section{Results}

The distribution maps for the taxa studied, based on the UTM $1 \mathrm{~km}^{2}$ grid, are shown in Figs $2 \& 3$ and the results of the risk assessment are presented in Supplementary Table $\mathrm{S} 1$ and Table 2. Of the 16 taxa evaluated we categorized three as Near Threatened, two as Vulnerable, eight as Endangered and three as Critically Endangered.

We identified two main groups of threats to these endemic plants: human activities and invasion by alien species. The main threats associated with invasive alien species are those that directly affect habitats and/or species as competitors or predators (code 8.1.2; IUCN, 2012), with 10 taxa affected. Predation by free-roaming goats is a threat to seven taxa (code 2.3). Six taxa are indirectly affected by loss of habitat as a result of human activities (code 7.3) and eight taxa by changes in vegetation dynamics (code 8.2.1). Human influence involves infrastructure, tourism and recreational activities (codes 1.1, 1.3, 4.1 and 5.2.1, nine taxa affected). Landslides are a minor threat (code 10.3), affecting only the Giglio subpopulation of L. capraria (Coppi et al., 2013).
All taxa apart from three localized species (Limonium doriae, $R$. insularis and Silene capraria) were present in at least two locations and not all populations were under threat. The number of locations was higher for species occurring on more than one island, with L. capraria and Limonium sommierianum having the highest number of locations, on five and three islands, respectively, and for Limonium ilvae, which occurs along the coast of Elba.

\section{Discussion}

Of the 16 endemic taxa, eight are Endangered and three are Critically Endangered. IUCN criterion B was the most commonly used for risk categorization, perhaps because of the ease of collecting reliable distribution data (Rossi et al., 2008b). In this study the use of criterion B has resulted in higher risk categories compared with categorization based on number of individuals. Both measures of Area of Occupancy (based on UTM grids of 1 and $4 \mathrm{~km}^{2}$ ) led to the same Red List categorization. Hence species with a large 
TABLE 2 Previous status and proposed threat category of the 16 taxa studied. Risk values are assigned to IUCN Red List categories as follows: LC or NT, 1; VU, 2; EN, 3; CR, 4 .

\begin{tabular}{|c|c|c|c|c|c|c|}
\hline & $\begin{array}{l}\text { Conti et al. } \\
(1997)^{\star}\end{array}$ & $\begin{array}{l}\text { Risk } \\
\text { value }\end{array}$ & $\begin{array}{l}\text { Sposimo \& } \\
\text { Castelli }(2005)^{\star}\end{array}$ & $\begin{array}{l}\text { Risk } \\
\text { value }\end{array}$ & $\begin{array}{l}\text { Proposed } \\
\text { category }^{*}\end{array}$ & $\begin{array}{l}\text { Risk } \\
\text { value }\end{array}$ \\
\hline Biscutella pichiana subsp. ilvensis & LR & 1 & LR & 1 & EN & 3 \\
\hline Centaurea aetaliae & & & CR & 4 & EN & 3 \\
\hline Centaurea gymnocarpa & VU & 2 & VU & 2 & EN & 3 \\
\hline Centaurea ilvensis & & & CR & 4 & VU & 2 \\
\hline Crocus ilvensis & & & & & EN & 3 \\
\hline Festuca gamisansii subsp. aethaliae & LR & 1 & VU & 2 & VU & 2 \\
\hline Limonium doriae & VU & 2 & VU & 2 & CR & 4 \\
\hline Limonium gorgonae & LR & 1 & LR & 1 & EN & 3 \\
\hline Limonium ilvae & LR & 1 & LR & 1 & NT & 1 \\
\hline Limonium planesiae & LR & 1 & LR & 1 & EN & 3 \\
\hline Limonium sommierianum & LR & 1 & LR & 1 & NT & 1 \\
\hline Linaria capraria & LR & 1 & LR & 1 & NT & 1 \\
\hline Mentha requienii subsp. bistaminata & LR & 1 & LR & 1 & $\mathrm{EN}$ & 3 \\
\hline Romulea insularis & VU & 2 & VU & 2 & CR & 4 \\
\hline Silene capraria & & & CR & 4 & CR & 4 \\
\hline Viola corsica subsp. ilvensis & LR & 1 & $\mathrm{VU}$ & 2 & EN & 3 \\
\hline Total risk-value & & 15 & & 29 & & 43 \\
\hline
\end{tabular}

${ }^{\star}$ LC, Least Concern (including LR, Lower Risk, in the old IUCN categorization); NT, Near Threatened; VU, Vulnerable; EN, Endangered; CR, Critically Endangered

population but a narrow distribution, such as $R$. insularis (population c. 1 million), may nevertheless be categorized as Critically Endangered. Many species are under threat as a result of changes in habitat management (Wilcove et al. 1998; Rossi et al., 2008b). We categorized three species as Critically Endangered ( $L$. doriae, $R$. insularis and $S$. capraria). The main threats to these species in the summit area of Capraia Island are a result of the abandonment of agricultural activities. These small species prefer open habitat such as Isoëto-Nanojunceta temporary ponds and Tuberarietea therophytic grasslands (Natura 2000 habitat codes 3170 and 6220 , respectively, according to Directive 92/43/ECE; both are conservation priorities), which are maintained by mild anthropogenic disturbance that slows the development of woody vegetation. They are threatened by the presence of scrub or tall forbs, which have arisen following the abandonment of agropastoral management. To avoid the invasion of scrub vegetation, two LifeNat projects have been established. The first results (Foggi et al., 2009) indicate an improvement in habitat quality for $R$. insularis but conservation actions will need to be incorporated into standard management. The five species belonging to the genus Limonium are suffrutex that inhabit chasmophytic or lithophytic aeroaline coastal habitats. They are threatened by coastal development for tourism, and the increasing numbers of invasive species introduced in the gardens of new settlements. For several species on Elba (e.g. Centaurea aetaliae, Centaurea ilvensis and $L$. capraria), walls and road escarpments are important corridors of secondary habitat, facilitating interaction between isolated populations (Guidi, 2010). The survival of these species is threatened by management of roadside vegetation, which is usually carried out during the flowering period (April-June). This type of threat could be mitigated by establishing management guidelines for local authorities.

Invasive plant and animal species, both alien and native, are the second most significant threat to the endemic plant species of the Tuscan Archipelago, affecting 14 of the 16 endemic taxa. These invasive species have a negative effect on populations of the endemic species and drive indirect changes in the dynamics of the local vegetation. They can also facilitate the arrival of nitrophilous and/or cosmopolitan species, as reported for small islands (Foggi et al., 2000), or of other invasive alien species such as Carpobrotus acinaciformis, Senecio angulatus and Opuntia spp., which affect C. gymnocarpa in Capraia (Foggi, 2005). Invasive alien animal species such as goats Capra hircus, wild boars Sus scrofa, black rats Rattus rattus and mouflons Ovis orientalis musimon affect, to varying degrees, populations of Biscutella pichiana subsp. ilvensis, Centaurea ilvensis, C. aetaliae, Crocus ilvensis, Festuca gamisansii subsp. aethaliae, L. capraria and Viola corsica subsp. ilvensis. The problem of invasive species is amplified in insular ecosystems (Whittaker \& Fernándes-Palacios, 2007) and could be deleterious for strictly localized species, especially in view of potential climate-change scenarios (Kier et al., 2009). Eradication programmes have been implemented for several alien plant species (Giunti et al., 2009; Sposimo et al., 2011) but their results have yet to be verified. In the case of $L$. doriae, threats posed by the 
invasive alien plant Arundo donax and by the nitrophilous Atriplex hastata and Portulaca oleracea are driven by an increase in the seagull population (Foggi et al., 2000). The persistence of these invasive plants could lead to the extinction of $L$. doriae, and therefore we assess this species as Critically Endangered.

The Convention on Biological Diversity recognizes the problem of invasive alien species as a focal point for conservation $(\mathrm{CBD}, 2010)$ in its strategic goals for 2020: 'By 2020, invasive alien species and pathways are identified and prioritized, priority species are controlled or eradicated, and measures are put in place to manage pathways to prevent their introduction and establishment'. The study of alien invasion processes in the Tuscan Archipelago has begun, along with several other actions funded by the Tuscan Archipelago National Park and by the Tuscany Regional Administration (Viciani et al., 2014). Studies have revealed an increase in the number of alien species detected over recent decades (Lastrucci et al., 2012; Lazzaro et al., 2013), from 69 species at the beginning of the 1980s (Viegi \& Cela Renzoni, 1981) to 171 species in 2013 (Foggi et al., unpubl. data), most of which were introduced for horticultural and gardening purposes.

As mentioned in the introduction, some published documents (Conti et al., 1997; Sposimo \& Castelli, 2005) report IUCN Red List categories for several endemic plants of the Tuscan Archipelago. Although the status reported in these documents does not arise from a strict application of the IUCN categories and criteria (Rossi et al., 2008a) we can use these data for comparison. In Table 2 we indicate the past and present status of the studied taxa, with the exception of Crocus ilvensis, which was described in 2011. Apart from L. capraria all have been recategorized with a higher degree of threat. The total risk value shows an increase in the risk of extinction. This is in accordance with Kier et al. (2009): 'while island and mainland regions suffered equally from past habitat loss, we find the human impact index, a measure of current threat, to be significantly higher on islands'. The scarcity of information (distribution data, population size) up to 2005 was addressed during 2007-2011, when increases in the Area of Occupancy and Extent of Occurrence were recorded. It is likely that the increased threat to the survival of the endemic flora of the Tuscan Archipelago since 1997 (Conti et al., 1997) is related to the increase in the number of taxa and number of individuals of alien species.

Since the establishment of the Tuscan Archipelago National Park in 1991, several actions have been taken (habitat conservation, eradication of invasive alien plants and animals, education of young people) to counteract the loss of biodiversity (Zanichelli \& Giannini, 2008). However, as the most significant threats are anthropogenic, a sustainable solution will require a systemic and interdisciplinary approach to biodiversity conservation (Delanoë et al., 1996). For all species studied, and particularly for those categorized as Critically Endangered, in situ conservation measures need to be integrated with ex situ programmes (Smith et al., 2010), providing source material for reintroduction projects (Foggi et al., 2011b; Carta et al., 2012).

Given their high levels of endemism and species richness, islands may offer high returns for species conservation efforts and therefore warrant high priority in global biodiversity conservation (Kier et al., 2009). Given the limited resources available to implement biodiversity conservation policies (Balmford et al., 2005), we recommend an integrated approach to conservation of the flora of the Tuscan Archipelago, combining the IUCN criteria with other criteria not included in the IUCN scheme (Gauthier et al., 2010; Bacchetta et al., 2012). This study may be considered the first attempt to assess priorities among species for inclusion in ex situ and in situ conservation programmes (Gauthier et al., 2010; Jiménez-Alfaro et al., 2010) in the Tuscan Archipelago.

\section{Acknowledgements}

This research was supported by funding from the Tuscan Archipelago National Park, which also permitted the collection of plant material. We thank the IUCN Species Survival Commission for the use of an ArcGIS license.

\section{References}

Anderson, S. (1994) Area and endemism. The Quarterly Review of Biology, 69, 451-471.

Arrigoni, P.V., B Aldini, R.M., Foggi, B. \& Signorini, M.A. (2003) Analysis of the floristic diversity of the Tuscan Archipelago for conservation purposes. Bocconea, 16, 245-259.

Bacchetta, G., Farris, E. \& Pontecorvo, C. (2012) A new method to set conservation priorities in biodiversity hotspots. Plant Biosystems, 146, 638-648.

Balmford, A., Bennun, L., ten Brink, B., Cooper, D., Côté, I.M., Crane, P. et al. (2005) The Convention on Biological Diversity's 2010 Target. Science, 307, 212-213.

Butchart, S.H.M., Walpole, M., Collen, B., van Strien, A., Scharlemann, J.P.W, Almond, R.E.A. et al. (2010) Global biodiversity: indicators of recent declines. Science, 328, 1164-1168.

Carta, A., Bedini, G., Foggi, B. \& Probert, R.J. (2012) Laboratory germination and seed bank storage of Ranunculus peltatus subsp. baudotii seeds from the Tuscan Archipelago. Seed Science and Technology, 40, 11-20.

CBD (Convention on Biological Diversity) (2010) Http:// www.cbd.int/ [accessed 24 February 2014].

Ceballos, G., Rodriguez, P. \& Medellin, R.A. (1998) Assessing conservation priorities in megadiverse Mexico: mammalian diversity, endemicity, and endangerment. Ecological Applications, $8,8-17$.

Conti, F., Manzi, A. \& Pedrotti, F. (1997) Liste Rosse Regionali delle Piante d'Italia, pp. 139. Società Botanica Italiana, Florence, Italy.

Coppi, A., Guidi, T., Viciani, D. \& Foggi, B. (2013) Genetic structure of Linaria capraria Mill. (Plantaginaceae) and endemic species of the Tuscan Archipelago (central Mediterranean). Plant Biosystems. 
Http://dx.doi.org/10.1080/11263504.2012.762948 [accessed 24 February 2014].

Costion, C.M., Kitalong, A.I. \& Holm, T. (2009) Plant endemism, rarity, and threat in Palau, Micronesia: a geographical checklist and preliminary Red List assessment. Micronesica, 41, 131-164.

Cuttelod, A., García, N., Abdul Malak, D., Temple, H. \& Katariya, V. (2008) The Mediterranean: a biodiversity hotspot under threat. In The 2008 Review of the IUCN Red List of Threatened Species (eds J.C. Vié, C. Hilton-Taylor \& S.N. Stuart), pp. 1-13. IUCN, Gland, Switzerland.

Delanoë, O., De Montmollin, B. \& Olivier, L. (1996) Conservation of Mediterranean Island Plants. 1. Strategy for Action. IUCN, Gland, Switzerland.

De Montmollin, B. \& Strahm, W. (eds) (2005) The Top 50 Mediterranean Island Plants: Wild Plants at the Brink of Extinction, and What is Needed to Save Them. IUCN/SSC Mediterranean Islands Plant Specialist Group. IUCN, Gland, Switzerland, and Cambridge, UK.

Domínguez lozano, F., Galicia Herbada, D., Moreno Rivero, L., Moreno Saiz, J.C. \& Sainz Ollero, H. (1996) Threatened plants in peninsular and Balearic Spain: a report based on the EU Habitats Directive. Biological Conservation, 76, 123-133.

Ellstrand, N.C. \& Elam, D.R. (1993) Population genetic consequences of small population sizes: implications for plant conservation. Annual Review of Ecology and Systematics, 24, 217-242.

Fenu, G., Mattana, E. \& Bacchetta, G. (2011) Distribution, status and conservation of a Critically Endangered, extremely narrow endemic: Lamyropsis microcephala (Asteraceae) in Sardinia. Oryx, 45, 180-186.

Fenu, G., Mattana, E. \& Bacchetta, G. (2012) Conservation of endemic insular plants: the genus Ribes L. (Grossulariaceae) in Sardinia. Oryx, 46, 219-222.

FJELDSÅ, J. (1994) Geographical patterns for relict and young species of birds in Africa and South America and implications for conservation priorities. Biodiversity and Conservation, 3, 207-226.

FogGI, B. (2005) Centaurea gymnocarpa. In The Top 50 Mediterranean Island Plants: Wild Plants at the Brink of Extinction, and What is Needed to Save Them (eds B. de Montmollin \& W. Strahm), pp. 104-105. IUCN/SSC Mediterranean Islands Plant Specialist Group, Gland, Switzerland, and Cambridge, UK.

Foggi, B. \& Pancioli, V. (2008) Contributo alla conoscenza della Vegetazione dell'Isola del Giglio (Arcipelago Toscano, Grosseto). Webbia, 63, 25-48.

Foggi, B., Cartei, L. \& Pignotti, L. (2008) La vegetazione dell'isola di Pianosa (Arcipelago Toscano). Braun-Blanquetia, 43, 3-41.

Foggi, B., Cartei, L., Pignotti, L., Signorini, M.A., Viciani, D., Dell'Olmo, L. \& Menicagli, E. (2006) Il paesaggio vegetale dell'Isola d'Elba (Arcipelago toscano): studio fitosociologico e cartografico. Fitosociologia, 43(Suppl. 1), 3-94.

Foggi, B., Cioffi, V., Ferretti, G., Dell'Olmo, L., Viciani, D. \& Lastrucci, L. (2011a) La vegetazione dell'Isola di Giannutri (Arcipelago Toscano). Fitosociologia, 48, 23-44.

Foggi, B., Guidi, T., Venturi, E. \& Ghisolfi, M. (2009) Interventi per la conservazione dell'habitat 'Stagnetti temporanei mediterranei' nell'isola di Capraia: primi risultati. Atti della Società Toscana di Scienze Naturali, Memorie serie B, 115, 47-56.

Foggi, B., Lastrucci, L., Viciani, D., Brunialti, G. \& BENESPERI, R. (2011b) Long-term monitoring of an invasion process: the case of an isolated small wetland. Biologia, 66, 638-644.

Foggi, B., Signorini, M.A., Grigioni, A. \& Clauser, M. (2000) La vegetazione di alcuni isolotti dell'Arcipelago toscano. Fitosociologia, $37,69-92$.
Fossi Innamorati, T. (1991) La flora vascolare dell'Isola d'Elba (Arcipelago Toscano). Parte terza. Webbia, 45, 137-185.

Frignani, F. \& IIRIti, G. (2011) The genus Romulea in Italy: taxonomy, ecology and intraspecific variation in relation to the flora of Western Mediterranean Islands. Fitosociologia, 48(Suppl. 1), $13-20$.

Gauthier, P., Debussche, M. \& Thompson, J.D. (2010) Regional priority setting for rare species based on a method combining three criteria. Biological Conservation, 143, 1501-1509.

Giunti, M., Sposimo, P. \& Foggi, B. (2009) Rimozione specie alloctone vegetali, salvaguardia di prati di terofite annue e tutela di un impianto di leccio nell'Isola di Capraia (LI). Nemo s.r.l., Parco Nazionale Arcipelago Toscano.

Greuter, W. (1991) Botanical diversity, endemism, rarity and extinction in the Mediterranean area: an analysis based on the published volume of Med-Checklist. Botanika Chronika, 108, 63-79.

Gruttke, H., Ludvig, G., Binot-Hafke, M. \& Rieken, U. (1999) Perspektiven bundesweiter Roten Listen-Ergebnisse eines Symposium des Bundesamtes für Naturschutz. Natur und Landschaft, 74, 281-284.

Guidi, T. (2010) Le piante endemiche dell'Arcipelago Toscano. Valutazione della vulnerabilità. $\mathrm{PhD}$ thesis. Scuola di Dottorato 'Ubaldo Montelatici', Dottorato in Biosistematica vegetale, ciclo XXI, Università degli Studi di Firenze.

Işı , K. (2011) Rare and endemic species: why are they prone to extinction? Turkish Journal of Botany, 35, 411-417.

IUCN (2001) IUCN Red List Categories. Version 3.1. IUCN Species Survival Commission Re-introduction Specialist Group, World Conservation Union, Gland, Switzerland, and Cambridge, UK.

IUCN (2011) Guidelines for Using the IUCN Red List Categories and Criteria: Version 9. IUCN-SSC, Biodiversity Sub-committee, Gland, Switzerland.

IUCN (2012) IUCN-CMP Unified Classification of Direct Threats. Version 3.1. Http://www.iucnredlist.org/documents/June_2012_ Guidance_Threats_Classification_Scheme.pdf [accessed 24 February 2014].

IUCN (2013) Aquatic Plants. Http://www.iucnredlist.org/initiatives/ mediterranean/mediterraneanaquaticplants [accessed 20 February 2014].

Jiménez-Alfaro, B., Colubi, A. \& González-Rodríguez, G. (2010) A comparison of point-scoring procedures for species prioritization and allocation of seed collection resources in a mountain region. Biodiversity and Conservation, 19, 3667-3684.

Kier, G., Kreft, H., Lee, M.T., Jetz, W., Ibisch, P.L., Nowiki, C. et al. (2009) A global assessment of endemism and species richness across island and mainland regions. Proceedings of the National Academy of Sciences of the United States of America, 106, 9322-9327.

Lastrucci, L., Calamassi, R., Ferretti, G., Galasso, G. \& FOGGI, B. (2012) Contributo alla conoscenza della flora esotica dell'Isola di Capraia (Arcipelago Toscano, Italia). Atti Società Italiana di Scienze Naturali e Museo civico Storia naturale di Milano, 153, 127-134.

Lazzaro, L., Ferretti, G., Galasso, G., Lastrucci, L. \& Foggi, B. (2013) Contributo alla conoscenza della flora esotica dell'Arcipelago Toscano, Italia. Atti Società Italiana di Scienze Naturali e Museo civico Storia naturale di Milano, 154, 3-24.

LiNDER, H.P. (1995) Setting conservation priorities-the importance of endemism and phylogeny in the southern African orchid genus Herschelia. Conservation Biology, 9, 585-595.

Mace, G.M., Collar, N.J., Gaston, K.J., Hilton-Taylor, C., Akcakaya, H.R., Leader-Williams, N. et al. (2008) Quantification of extinction risk: IUCN's system for classifying threatened species. Conservation Biology, 22, 1424-1442. 
Martin, J.L. (2009) Are the IUCN standard home-range thresholds for species a good indicator to prioritise conservation urgency in small islands? A case study in the Canary Islands (Spain). Journal for Nature Conservation, 17, 87-98.

MÉdAIL, F. \& QUÉZel, P. (1997) Hot-spots analysis for conservation of plant biodiversity in the Mediterranean basin. Annals of the Missouri Botanical Garden, 84, 112-127.

Médail, F. \& Verlaque, R. (1997) Ecological characteristics and rarity of endemic plants from southeast France and Corsica: implications for biodiversity conservation. Biological Conservation, $80,269-281$.

Miller, R.M., Rodríguez, J.P., Aniskowicz-Fowler, T., Bambaradeniya, C., Boles, R., Eaton, M.A. et al. (2007) National threatened species listing based on IUCN criteria and regional guidelines: current status and future perspectives. Conservation Biology, 21, 684-696.

Mittermeier, R.A., Gil, P.R., Hoffman, M., Pilgrim, J., Brooks, T., Mittermeier, C.G. et al. (2004) Hotspots Revisited. University of Chicago Press, Chicago, USA.

Myers, N., Mittermeier, R.A., Mittermeier, C.G., DA Fonseca, G.A.B. \& Kent, J. (2000) Biodiversity hotspots for conservation priorities. Nature, 403, 853-858.

Papayannis, T. \& Sorotou, A. (2008) Cultural landscapes of Mediterranean islands. In Mediterranean Island LandscapesNatural and Cultural Approaches (eds I.N. Vogiatzakis, G. Pungetti \& A.M. Mannion), pp. 82-99. Springer, London, UK.

Peruzzi, L. \& Carta, A. (2011) Crocus ilvensis sp. nov. (sect. Crocus, Iridaceae), endemic to Elba Island (Tuscan Archipelago, Italy). Nordic Journal of Botany, 29, 6-13.

Pimm, S.L., Russell, G.J., Gittleman, J.L. \& Brooks, T.M. (1995) The future of biodiversity, Science, 269, 347-350.

Rivers, M.C., Bachman, S.P., Meagher, T.R., Nic Lughadha, E. \& BrummitT, N.A. (2009) Subpopulations, locations and fragmentation: applying IUCN Red List criteria to herbarium specimen data. Biodiversity and Conservation, 19, 2071-2085.

Robbirt, K.M., Roberts, D.L. \& Hawkins, J.A. (2006) Comparing IUCN and probabilistic assessments of threat: do IUCN Red List criteria conflate rarity and threat? Biodiversity and Conservation, 15, 1903-1912.

Rossi, G. \& Gentili, R. (2008) A partnership project for a new Red List of the Italian flora. Plant Biosystems, 142, 302-304.

Rossi, G., Gentili, R., Abeli, T. \& Foggi, B. (2008a) La redazione di Liste Rosse per la conservazione della flora spontanea. In Flora da conservare, implementazione delle categorie e dei criteri IUCN (2001) per la redazione di nuove Liste Rosse (eds G. Rossi, R. Gentili, T. Abeli, D. Gargano, B. Foggi, F.M. Raimondo \& C. Blasi), pp. 17-21. Informatore Botanico Italiano, Florence, Italy.

Rossi, G., Gentili, R., Abeli, T., Gargano, D. \& Foggi, B. (2008b) Discussione e considerazioni conclusive. In Flora da conservare, implementazione delle categorie e dei criteri IUCN (2001) per la redazione di nuove Liste Rosse (eds G. Rossi, R. Gentili, T. Abeli, D. Gargano, B. Foggi, F.M. Raimondo \& C. Blasi), pp. 155-159. Informatore Botanico Italiano, Florence, Italy.

SCBD (Secretariat of the Convention on Biological Diversity) (2010) Global Biodiversity Outlook 3. Http://www.cbd. int/doc/publications/gbo/gbo3-final-en.pdf [accessed 24 February 2014].

Schnittler, M. \& Ludwig, G. (1996) Zur Methodik der Erstellung Roten Listen. Schriftenreihe für Vegetationskunde, 28, 109-739.

Smith, P., Dickie, J., Linington, S., Probert, R. \& Way, M. (2010) Making the case for plant diversity. Seed Science Research, 21, 1-4.

Sposimo, P., Baccetti, N., Raganella Pelliccioni, E., Gubert, V., Giannini, F. \& Capizzi, D. (2011) Piano per l'eradicazione del ratto nero Rattus rattus nell'isola di Montecristo (Arcipleago Toscano). Life-Project NAT/IT/0oo353 - Montecristo 2010: eradicazione di componenti floro-faunistiche aliene invasive e tutela di specie e di habitat nell'Arcipelago Toscano. Http://www. montecristo2010.it/stealthV3_pubblica/0810372AOO7595000015.pdf [accessed 24 February 2014].

Sposimo, P. \& CAstelli, C. (2005) La biodiversità in Toscana. Specie e habitat in pericolo. Archivio del Repertorio Naturalistico Toscano (RENATO), pp. 304. Regione Toscana, Firenze, Direzione Generale Politiche Territoriali e Ambientali. Tipografia Il Bandino, Firenze.

Thompson, J.D. (1999) Population differentiation in Mediterranean plants: insights into colonization history and the evolution and conservation of endemic species. Heredity, 82, 229-236.

Trigas, P., Iatrou, G. \& Panitsa, M. (2008) Vascular plant species diversity, biogeography and vulnerability in the Aegean islands as exemplified by Evvia island (W Aegean, Greece). Fresenius Environmental Bulletin, 17, 48-57.

Viciani, D., Albanesi, D., Dell'Olmo, L. \& Foggi, B. (2011) Contributo alla conoscenza della vegetazione dell'Isola di Gorgona (Arcipelago Toscano) (con carta in scala 1:5.00o). Fitosociologia, $48,45-64$.

Viciani, D., Lastrucci, L., Dell'Olmo, L., Ferretti, G. \& FogGI, B. (2014) Natura 2000 habitats in Tuscany (central Italy): synthesis of main conservation features based on a comprehensive database. Biodiversity and Conservation, 23, 1551-1576.

Viegi, L. \& Cela Renzoni, G. (1981) Flora esotica d'Italia: le specie presenti in Toscana. Consiglio Nazionale delle Ricerche, Pavia, Italy.

Whittaker, R.J. \& Fernández-Palacios, J.M. (2007) Island Biogeography. Oxford University Press, Oxford, UK.

Wilcove, D.S., Rothstein, D., Dubow, J., Phillips, A. \& Losos, E. (1998) Quantifying threats to imperiled species in the United States: assessing the relative importance of habitat destruction, alien species, pollution, over-exploitation, and disease. BioScience, 48, 607-616.

Zanichelli, F. \& Giannini, F. (eds) (2008) Progetto Life Natura, Isole di Toscana: nuove azioni per uccelli marini e habitat. I Quaderni del Parco, documenti tecnici n. 1. Parco Nazionale Arcipelago Toscano, Italy.

\section{Biographical sketches}

BRUNO FOGgI and RICCARDO BALDINI have a particular interest in the flora of the Tuscan Archipelago. D a niele Viciani carries out geobotanical analysis in the western Mediterranean. Angelino CARTA is interested in ex-situ conservation. TOMmASo Guid has a particular interest in modelling species distribution areas. 